\section{Reversal of premature hair greying in adult coeliac disease}

There is no known association between premature greying of the hair and the subsequent diagnosis of adult coeliac disease. I report two cases in which the hair colour turned completely during the third decade and remained unchanged until adult coeliac disease was diagnosed at least 20 years later. In both cases a reversal of the colour change began a few weeks after starting a gluten-free diet.

\section{Case reports}

(1) The patient, a man, had had dark brown hair until the age of 25 . Discoloration progressed until at the age of 30 the scalp hair was snow white. Other body hair was unaffected and he remained in good health. At the age of 53 he was admitted to hospital after an accident and was found to be anaemic. The results of investigations, including jejunal biopsy, were consistent with adult coeliac disease. Institution of a gluten-free diet led to resolution of the anaemia. Within three months of starting the diet his hair was noticeably darker at the temples. Within five years his hair was quite

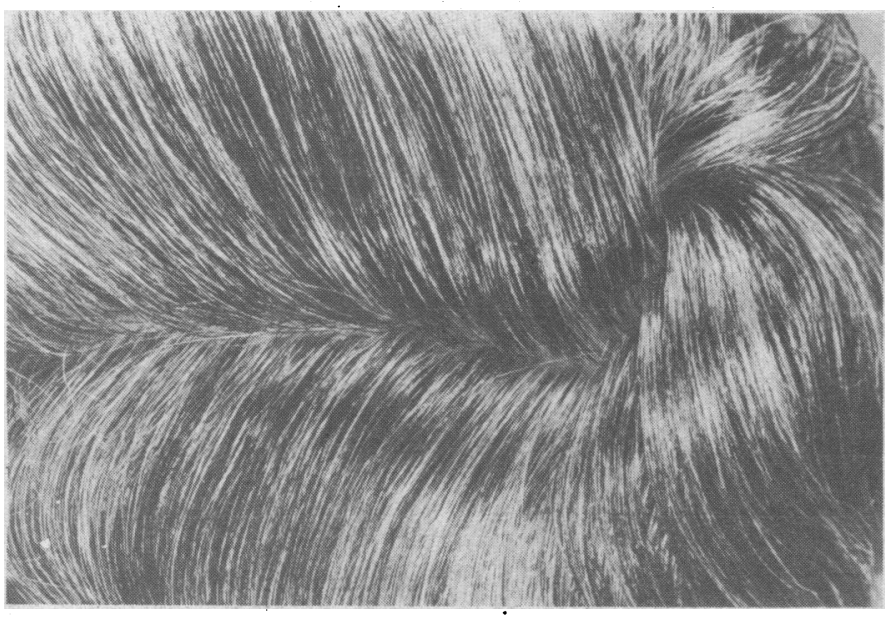

Hair banding related to clinical relapse of adult coeliac disease.

dark but with streaks of grey, appropriate for his age of 58. Later his bowe action of two soft stools daily changed to one firm stool daily, but he could not remember if his bowel action had ever been different in his youth A deliberate gluten meal caused diarrhoea, which settled over six weeks, and the freshly emerging hair became light grey once more, returning to the darker colour as the diarrhoea settled. A second gluten meal caused a repetition and obvious bands could be seen (figure).

(2) The patient, a woman, had lost her dark brown hair colour during her late thirties and became completely white by the age of 43 . She had recurrent iron-deficient anaemia which was attributed to menorrhagia until after the menopause, when she was investigated. The findings, including jejunal biopsy, suggested adult coeliac disease. Within a few weeks of starting a glutenfree diet at the age of 58 her hairdresser commented that her hair was growing out darker, and by the age of 63 its appearance strikingly resembled that of the first patient. The hair change was restricted to scalp hair and there was no alteration of bowel habit, but she felt much better.

\section{Comment}

The hair appearance may change in childhood protein deficiency states $^{1}$ and in inborn errors of amino-acid metabolism. ${ }^{2}$ The reason for the change is unknown but perhaps abnormal amino-acid concentrations in the body fluids produce abnormal protein. Patients with phenylketonuria have an abnormally high phenylalanine content in their imperfectly pigmented hair, ${ }^{3}$ and patients with kwashiorkor have a deficiency in the number of melanosomes in the cornified hair ${ }^{4}$ and a reduction in the amount of sulphur-containing protein with corresponding depigmentation. ${ }^{5}$ The amino-acid content of hair samples from the patient in case 1 was analysed, comparing dark and light zones. There was no difference in the concentration of 17 standard amino-acids and the values obtained were within normal ranges. ${ }^{3}$ Possibly minor differences were not shown and more subtle changes would be expected in coeliac disease than in much more florid deficiency states. Also the sulphur-containing amino-acids are difficult to assay accurately ${ }^{5}$ and it is these that are concerned in maintaining the three-dimensional structure of protein fundamental in the determination of colour.

Although the mechanism of the hair colour changes in these two cases is not clear its connection with gluten sensitivity is undoubted. Perhaps this type of premature greying is either the presenting sign of adult coeliac disease or is a coincidental predictor of its later occurrence.

1 Jolly H. Diseases of children. Oxford: Blackwell Scientific Publications, 1976:546.

2 Vellan EJ, Gjessing LR, Seip M. Hair amino-acids in cystinosis, homocystinuria, Fölling's disease and tyrosinosis. Acta Paediatr Scand 1969; 58:287-9.

3 Van Sande M. Hair amino acids: normal values and results in metabolic errors. Arch Dis Child 1970;45:678-81.

${ }^{4}$ Sims RT. An introduction to the biology of the skin. Oxford: Blackwell Scientific Publications, 1970:387.

5 Pollitt RJ, Stonier PD. Proteins of normal hair and of cystine deficient hair from mentally retarded siblings. Biochem $\mathcal{F} 1971$;122:433-44.

(Accepted 28 March 1980)

Peterborough District Hospital, Peterborough PE3 6DA LAWFORD S HILL, MB, MRCP, senior medical registrar

\section{Acute renal failure and myopathy after treatment with aminocaproic acid}

Epsilon aminocaproic acid (aminocaproic acid) is increasingly being used to inhibit fibrinolysis in subarachnoid haemorrhage. We report a case in which acute massive muscle necrosis and acute renal failure occurred after treatment.

\section{Case history}

A 20-year-old nursery nurse was admitted to hospital with a typical subarachnoid haemorrhage confirmed by lumbar puncture. Carotid angiography and CT scan showed a large right-sided arteriovenous malformation. She was given aminocaproic acid $30 \mathrm{~g}$ daily for seven weeks. After six weeks' treatment myalgia, haematuria, and proteinuria were noted. Over the next week this progressed to profound muscle weakness and severe respiratory impairment. Despite previously normal renal function she developed acute oliguric renal failure necessitating haemodialysis.

Examination showed gross generalised flaccid weakness, and the muscles were so swollen and tender that physiotherapy was initially extremely difficult. Serum urate concentration was $0.57 \mathrm{mmol} / 1(9.6 \mathrm{mg} / 100 \mathrm{ml})$ sodium concentration $116 \mathrm{mmol} /(\mathrm{mEq}) / 1$, urea concentration $44.0 \mathrm{mmol} /$ $(265.0 \mathrm{mg} / 100 \mathrm{ml})$, potassium concentration $5.4 \mathrm{mmol}(\mathrm{mEq}) / \mathrm{l}$, and creatinine concentration $610 \mu \mathrm{mol} / 1(6.9 \mathrm{mg} / 100 \mathrm{ml})$. The table shows the serum creatine kinase and aspartate transaminase activities during weeks 1-5

Serum creatine kinase and aspartate transaminase activities during weeks 1-5

\begin{tabular}{|c|c|c|c|c|c|}
\hline Week: & 1 & 2 & 3 & 4 & 5 \\
\hline $\begin{array}{l}\text { Creatine kinase }(\mathrm{IU} / \mathrm{I}) \\
\text { Aspartate transaminase }(\mathrm{I} U / \mathrm{I}) \ldots\end{array}$ & $\begin{array}{r}22987 \\
242\end{array}$ & $\begin{array}{r}20504 \\
139\end{array}$ & $\begin{array}{r}1271 \\
104\end{array}$ & $\begin{array}{r}310 \\
10\end{array}$ & $\begin{array}{l}73 \\
35\end{array}$ \\
\hline
\end{tabular}

A muscle biopsy specimen showed acute, massive muscle necrosis with no evidence of polymyositis, polyarteritis, or any occlusive or thrombotic vessel disease. Results of other haematological investigations, tests for collagen diseases, virological studies, and chest radiography were normal.

After four weeks renal function recovered and the patient could sit upright with support. Three months later muscle power in all limbs was almost normal.

\section{Comment}

This report illustrates two grave consequences of treatment with aminocaproic acid, each of which is potentially lethal. The onset of acute massive myonecrosis six weeks after beginning treatment 
suggests a cumulative dose-related or time-related effect, or both. Nevertheless, many patients have taken up to $32 \mathrm{~g}$ daily for long periods without developing myopathy ${ }^{1}$ or acute renal failure, suggesting an idiosyncratic response. ${ }^{2}$ Other reports of acute renal failure $^{3}{ }^{4}$ after aminocaproic acid leave doubt about the mechanism concerned. None of the patients had the associated acute massive muscle necrosis seen in our case. We did not find myoglobin in either plasma or urine, so that this was unlikely to have been the mechanism of the acute renal failure. The overwhelming catabolism associated with myonecrosis might have created a crystallopathy with uric acid excretion, which may precipitate renal failure. Though renal function was reversible, aminocaproic acid may have a direct nephrotoxic effect, as evidenced by the disappearance of proteinuria ${ }^{5}$ on withdrawing the drug or reducing the dosage. No abnormalities of fibrin turnover or coagulation were detected, so that intravascular coagulation was unlikely. Renal biopsy was not performed because of the patient's respiratory impairment.

In view of the increasing emphasis on aminocaproic acid to control subarachnoid haemorrhage doctors should be aware of the possible consequences of such treatment. We propose routine measurement of creatine kinase activity and urine analysis in patients receiving long-term treatment.

We thank Mr J Moore-Robertson for allowing us to report this case, and Mr F Harper, Central Clinical Laboratory, for biochemical help. We also thank Miss M A Alston and Mrs J Harrison for secretarial work.

${ }^{1}$ Lane RJM, Mastaglia FL. Drug-induced myopathies in man. Lancet 1978 ;ii :562.

2 Lane RJM, Martin AM, McLelland NJ, Mastaglia FL. Epsilon aminocaproic acid (EACA) myopathy. Postgrad Med $\mathcal{f} 1979 ; 55: 282-5$.

3 Charyton C, Purtilo D. Glomerular capillary thrombosis and acute renal failure after epsilon aminocaproic acid therapy. $N$ Engl f Med 1969; 280:1102-4.

4 Stark SN, White JG, Langer LJR, Krivit W. Epsilon amino caproic acid therapy as a cause of intrarenal obstruction in haematuria of haemophiliacs. Scand $\mathcal{F}$ Haematol $1965 ; 2$ :99-107.

${ }^{5}$ Frank MM, Sergent JS, Kane MA, Alling DW. Epsilon aminocaproic acid therapy of hereditary angioneurotic edema. $N$ Engl $\mathcal{f}$ Med 1972; 286: 808-12.

(Accepted 15 April 1980)

Renal Unit, North Ormesby Hospital, Middlesbrough TS3 6HJ

C K BISWAS, MB, MRCP, registrar in renal and general medicine

D A REID MILLIGAN, $\mathrm{MB}$, $\mathrm{CHB}$, senior house officer in renal medicine $S$ D AGTE, $M B$, BS, senior house officer in renal medicine

D H KENWARD, MB, MRCP, consultant nephrologist

Department of Neurology, General Hospital, Middlesbrough TS5 $5 A Z$

P J B TILLEY, MB, MRCP, consultant neurologist

\section{Avascular necrosis of bone in children receiving high-dose steroid treatment}

Many reports ${ }^{1}$ have noted a possible association between steroid treatment and avascular necrosis of bone, but the exact relation remains unclear. We believe that the cases reported may have been examples of idiopathic avascular necrosis of bone in patients who coincidentally had undergone or were undergoing steroid treatment. Study of these and other cases shows that most patients had received steroid treatment for conditions themselves associated with avascular necrosis of bone or known to produce a radiographic appearance that might be confused with this condition-for example, rheumatoid arthritis, systemic lupus erythematosus, and after renal transplantation for chronic renal failure. In renal transplantation many factors may produce radiographic changes similar to those seen in avascular necrosis of bone-for example, osteomalacia, osteoporosis, and secondary and tertiary hyperparathyroidism.

No report exists of the incidence of avascular necrosis of bone in children receiving high-dose steroid treatment who have not undergone transplantation. We studied 28 such children with the nephrotic syndrome because this disease is of acute onset and has a low association with other forms of metabolic bone disease. Furthermore, these children rarely develop chronic renal failure and therefore do not undergo renal transplantation.

\section{Patients, methods, and results}

We contacted 28 children who had been treated with high doses of prednisone for renal disease (nephrotic syndrome 24 patients, HenochSchönlein nephritis two, and post-streptococcal nephritis two). All were well when examined; none had renal failure.

By using a standardised technique anteroposterior and lateral radiographs of both hips and knees were obtained, which included the upper and lowe thirds of the femoral shaft and the upper third of the tibial shaft. The radiographs were analysed blind by a radiologist and two orthopaedic surgeons, two of whom had special experience of the radiographic appearances of avascular necrosis of bone.

Steroid treatment was started at from 1 to 11 years (mean \pm SD $4.5 \pm 2 \cdot 9$ ). Ages at radiographic examination ranged from 4 to 20 years (mean $12 \cdot 6 \pm 5 \cdot 0$ ). The interval between these two events was one to 16 years (mean $8.0 \pm 3.9$ ) One patient was still undergoing steroid treatment when examined radiographically; in the remaining 27 the interval between stopping steroids and radiographic examination was one to 18 years (mean $6.3 \pm 3.9$ ). The initial dosage of prednisone given to all patients was $2 \mathrm{mg} / \mathrm{kg} /$ day (maximum $60 \mathrm{mg} /$ day); subsequent dosage depended on the response to treatment The cumulative dose ranged from 2.0 to $63.9 \mathrm{~g}$ (mean $6.9+11.7 \mathrm{~g}$-table) In addition 12 children received cyclophosphamide $2-4 \mathrm{mg} / \mathrm{kg} /$ day for two to three months. None of the radiographs contained any evidence of osteonecrosis.

Cumulative prednisone dose in 28 children studied

\begin{tabular}{lllllllllll}
\hline Prednisone dose $(\mathrm{g})$ & $0-$ & $2-$ & $4-$ & $6-$ & $8-$ & $10-$ & $12-$ & $14-$ & $16-$ \\
No of children & $\cdots$ & 7 & 4 & 5 & 4 & 6 & & & & 2 \\
\hline
\end{tabular}

\section{Comment}

The steroid dosage used in these children was similar to that given to children receiving kidney transplants, in $25 \%$ of whom a prospective study $^{2}$ showed radiographic evidence of osteonecrosis. The longest interval between starting treatment and onset of osteonecrosis in transplant patients is about three years, ${ }^{3}$ which had been passed in 25 of our cases; we therefore assume our nil incidence of avascular necrosis of bone to be correct, though the reasons for it are not clear. Most of the children were aged 10 or under during treatment, whereas in the transplant study ${ }^{2}$ all but one of the cases of avascular necrosis of bone occurred in children over 10; age during treatment may be important. The time over which the cumulative steroid dose is given and the rate at which the dose is changed may possibly be more important than the actual cumulative dose. In two other studies 5 the incidence of avascular necrosis of bone in children receiving steroids after renal transplantation was about $10 \%$ and, interestingly, steroid dosage was not significantly different between the children with and without the condition. Thus we suggest that in patients undergoing renal transplantation for chronic renal failure other factors may be more important than steroid treatment in the development of avascular necrosis of bone.

We wish to thank Dr P M Hacking and staff of the department of radiology, Royal Victoria Infirmary, Newcastle upon Tyne.

1 Pietrograndi V, Mastromarino R. Osteopatia da prolungato trattamento cortisonico. Ortopedia e Traumatologia dell' Apparato Motore 1957;25: 791-810.

2 Stern PJ, Watts HG. Osteonecrosis after renal transplantation in children. F Bone foint Surg 1979;61A:851-6.

${ }^{3}$ Catto M. Pathology of aseptic necrosis. In: Davidson JK, ed. Aseptic necrosis of bone. Amsterdam: Excerpta Medica, 1976:3-100.

${ }^{4}$ Uittenbogaart $\mathrm{CH}$, Isaacson MD, Stanley $\mathrm{P}$, et al. Aseptic necrosis after renal transplantation in children. Am $\mathcal{F}$ Dis Child 1978;132:765-7.

5 Potter DE, Genant HK, Salvatierra O. Avascular necrosis of bone after renal transplantation. Am $\mathcal{F}$ Dis Child 1978;132:1125-9.

(Accepted 15 April 1980)

Royal Victoria Infirmary, Newcastle upon Tyne NE1 4LP

P J GREGG, MD, FRCs, lecturer in orthopaedic surgery

M K BARSOUM, FRCS, orthopaedic registrar

D SOPPITT, MB, FRCR, consultant radiologist

R H JACKSON, BM, FRCP, consultant paediatrician 